\title{
At the forefront of congenital cardiothoracic surgery: 2020-2021
}

Igor E. Konstantinov, MD, PhD, FRACS, ${ }^{\text {a }}$ Carl L. Backer, MD, ${ }^{\mathrm{b}, \mathrm{c}}$ Can Yerebakan, MD, ${ }^{\mathrm{d}}$ and Bahaaldin Alsoufi, $\mathrm{MD}^{\mathrm{e}}$

The rapid progress and ever-expanding volume of literature in cardiothoracic surgery in children and adults with congenital heart disease necessitates providing our busy readership with condensed and cohesive information extracted from all 6 journals of the American Association for Thoracic Surgery. Our Editorial Board is committed to providing the readership with succinct yet detailed information on the hot topics viewed through the eyes of experts in the field. We aim to provide such highlights immediately before each annual American Association for Thoracic Surgery meeting. This compendium highlights Feature Expert Opinion articles, including the newly started Invited Expert Mini-Review series that appeared in our journals in 20202021.

\section{AORTIC AND TRUNCAL VALVE SURGERY}

Aortic valve surgery, including aortic root surgery, in children and adults with congenital heart disease has been prominently featured in the past year. ${ }^{1-4}$ It appears from the current literature that neonates and infants with congenital aortic stenosis have similar survival but improved freedom from reintervention when treated with aortic valve repair compared with balloon aortic dilatation. ${ }^{1}$ The Ross procedure is associated with high operative mortality in neonates and infants but low mortality and excellent freedom from reoperation in older children. $^{1,2}$ The initial aortic valve repair to delay Ross procedure beyond infancy and, ideally, into adolescence and adulthood appears to be a preferred strategy. ${ }^{1,2}$ Reversal of a Ross procedure is an interesting, although somewhat controversial, strategy in patients with a failing autograft. ${ }^{3}$

From the a Department of Cardiac Surgery, Royal Children's Hospital, Department of Paediatrics, University of Melbourne, Heart Research Group, Murdoch Children's Research Institute, Melbourne Centre for Cardiovascular Genomics and Regenerative Medicine, Melbourne, Australia; ${ }^{\mathrm{b}}$ Section of Pediatric Cardiothoracic Surgery, UK HealthCare Kentucky Children's Hospital, Lexington, Ky; 'Heart Institute and Cincinnati Children's Hospital Medical Center, Cincinnati, Ohio; ${ }^{\mathrm{d} C}$ Cardiac Surgery, Children's National Heart Institute, Washington, DC; and ${ }^{\mathrm{e}} \mathrm{De}-$ partment of Cardiothoracic Surgery, University of Louisville and Norton Children's Hospital, Louisville, Ky.

Received for publication March 18, 2021; revisions received March 18, 2021; accepted for publication March 23, 2021; available ahead of print April 20, 2021. Address for reprints: Igor E. Konstantinov, MD, PhD, FRACS, Royal Children's Hospital, Flemington Rd, Parkville 3052, Australia (E-mail: igor.konstantinov@rch. org.au).

J Thorac Cardiovasc Surg 2021;162:178-82

$0022-5223 / \$ 36.00$

Crown Copyright $\odot 2021$ Published by Elsevier Inc. on behalf of The American Association for Thoracic Surgery

https://doi.org/10.1016/j.jtcvs.2021.03.108
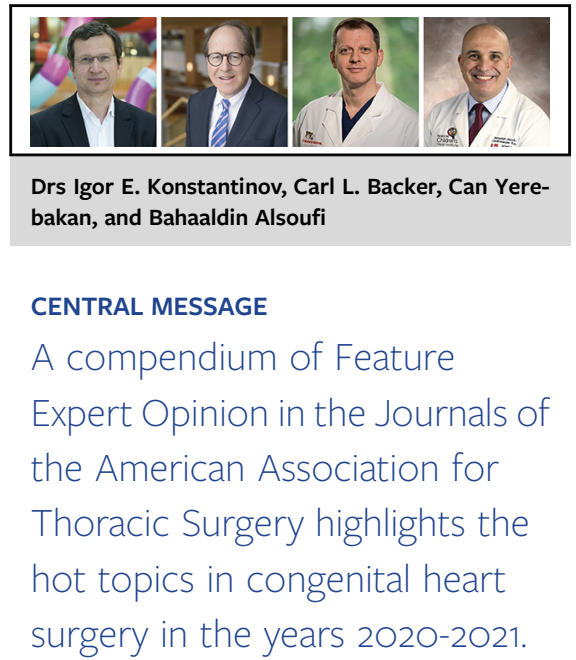

At the same time, valve-sparing aortic root surgery has emerged to restore aortic root geometry and, thus, salvage failing autograft following a Ross procedure. ${ }^{4}$ The valvesparing aortic root surgery, including external aortic root support, is spreading beyond its traditional application in patients with connective tissue disorders, with evolving indications in adult congenital patients with enlarged aortic root, including those after the arterial switch operation, tetralogy of Fallot repair, and univentricular palliations. ${ }^{4}$ Partial or complete Ozaki aortic valve replacement could be performed without operative mortality, but the long-term results in children are unknown and, thus, the place of the Ozaki procedure in aortic valve surgery in children is yet to be defined. ${ }^{1}$ Truncal valve repair in younger children remains challenging. It appears that reduction of the annulus is essential to emulate the natural anatomy of the aortic valve as close as possible and, thus, improve the durability of the truncal valve repair.

\section{MANAGEMENT OF TETRALOGY OF FALLOT}

Although it has been more than 60 years since the first intracardiac repair of tetralogy of Fallot, surgical management of this congenital heart defect remains an incredibly controversial topic. Strategies for these patients include primary neonatal versus staged repair, transatrialtranspulmonary versus transventricular repair, valvesparing versus transannular patch, and surgical pulmonary 
valve insertion versus transcatheter pulmonary valve. The recent article by Savla and colleagues ${ }^{6}$ in the Journal of the American College of Cardiology has fueled this controversy. Using data from 50 children's hospitals, the authors found that primary neonatal repair of tetralogy was associated with a significantly greater risk for early and 2-year mortality when compared with the staged approach. This led to a multitude of invited expert opinions and commentaries. ${ }^{7-10}$ Zurakowski and Jonas ${ }^{7}$ reviewed the general advantages of early primary repair of tetralogy and then enumerated factors driving a "re-emergence" of staged repair. These included a focus by institutions on early hospital mortality and the difficulty of teaching neonatal surgery in the current era. They also pointed out the limitations of administrative databases for such analysis. Fraser ${ }^{8}$ focused on the advantages of staged procedure and suggested to "reframe" the discussion and instead carefully evaluate multiple longitudinal outcomes. He highlighted that the article by Savla and colleagues ${ }^{6}$ demonstrates that there is in both groups a more significant 2-year attrition than contemporary practice acknowledges. Herrmann and Brown ${ }^{11}$ provided an Expert Opinion covering 7 decades of valved right ventricular outflow tract reconstruction, many of which were late interventions after tetralogy repair. They noted that pulmonary valve replacement was 5 times more common than any other valve replacement in pediatric cardiac surgery practices. Their preference appeared to be for bovine jugular vein conduits, decellularized pulmonary allografts, and stented porcine valves. In the absence of rigorous controlled trials, we often must continue to base our clinical decisions on expert opinions. ${ }^{12}$ The expanding indications for transcatheter pulmonary valve replacement were explored in depth by Tannous and Nugent. ${ }^{13}$ They reviewed the currently available transcatheter pulmonary valve devices and transcatheter approaches on the horizon for patients with native or nonconduit right ventricular outflow tracts. This, of course, is a field in which progress is accelerating with ever-improving devices from collaboration with industry. On a very different note, Bergmann ${ }^{14}$ provided an intriguing analysis on the possible role of cytokinesis failure in the cardiomyocytes of patients with tetralogy. Cytokinesis failure leads to a reduction in total myocyte number and, potentially, could make patients more prone to heart failure later in life. It appears that beta-blocker therapy delivered early in life could overcome cytokinesis failure and help generate new cardiomyocytes.

\section{MANAGEMENT OF PATIENTS WITH UNIVENTRICULAR CIRCULATION}

Surgical strategy and techniques have evolved in the hands of experts, now providing detailed description of the nuances of the Norwood operation. ${ }^{15}$ Despite the recent advances, neonates with hypoplastic left heart syndrome and intact or restrictive atrial septum remain at the greatest risk of death. ${ }^{16}$ Similar to other greater-risk patients among this population, hybrid strategies appear to provide a reasonable alternative to a neonatal surgical palliation with cardiopulmonary bypass.

The conundrum of the optimal Fontan operation in single-ventricle patients continues to challenge our surgical community. Daley and d'Udekem ${ }^{17}$ provided an excellent review of the literature of the most impactful papers on the comparison of lateral tunnel versus extracardiac conduits alternatives for the Fontan operation. The optimal venous pathway for Fontan circulation is yet to be determined in large trials. ${ }^{17,18}$ The guidelines of the American Heart Association on the current management of Fontan circulation were summarized and commented on by our surgical experts. ${ }^{19}$ Failing Fontan circulation presents an everincreasing challenge to our surgical community. A group of experts lead by Hraska ${ }^{20}$ reviewed the recent experience of interventional and surgical management of complications of impeded lymphatic drainage in Fontan circulation and discussed the rationale for and the outcomes of the innovative innominate vein turn-down procedure. While the indications for durable ventricular assist devices appear to evolve, it is clear that an early listing for heart transplantation before end-organ injury occurs is warranted. The results of heart transplantation in patients with Fontan circulation continue to improve with our better understanding of indications and timing of heart transplantation in these challenging patients. ${ }^{21,22}$

\section{MANAGEMENT OF PATIENTS WITH EBSTEIN ANOMALY AND SCIMITAR SYNDROME}

Management of Ebstein anomaly continues to be challenging due to the infrequency of cases seen by surgeons and the heterogeneity in this disease spectrum. The cone repair has become the preferred repair strategy in children and adults with Ebstein anomaly. Dearani ${ }^{23}$ discussed a large experience gained by the Mayo Clinic teams with about 400 cone repairs and provided detailed technical illustrations. Furthermore, Dearani described several modifications to improve repair durability and postoperative management strategy of atrial septal fenestration or using bidirectional cavopulmonary connection in those with right ventricular dysfunction. Neonates with severe Ebstein anomaly and right ventricular dysfunction have very high operative mortality and morbidity. Cleveland and Starnes ${ }^{24}$ discussed the management algorithm and advocated for early intervention within the first 72 hours of life in those who exhibit hemodynamic instability or require inotropic support. In addition, they described right ventricular remodeling following the Starnes procedure and the possibility for later conversion into one and half or biventricular repair.

The scimitar syndrome is another challenging problem. Similarly to Ebstein anomaly, there is a great heterogeneity in morphology and, consequently, anatomic manifestation 
of the disease, with neonates and infants having worse prognosis than their older counterparts. In addition, the rarity of this disease contributes to the persistent knowledge gap with regards to optimal treatment strategy. Vida and Guariento $^{25}$ presented experience gained from 485 patients, $58 \%$ of whom were diagnosed in infancy, from large multi-institutional databases. These patients diagnosed in infancy had a greater incidence of severe right lung hypoplasia, complex congenital heart disease, systemic arterial supply to the right lung, pulmonary hypertension, and congestive heart failure. The role of systemic arterial supply embolization and the occasional need for lung resection were discussed. It appears that currently used various surgical repair techniques were associated with a nearly $25 \%$ risk of late obstruction. This large retrospective review underscored the decision-making challenges and suboptimal surgical outcomes, despite an acceptable early and late survival that is linked to disease complexity and the age of presentation in patients with scimitar syndrome.

\section{RESEARCH AND EDUCATION}

The current state of cardiac stem cell therapy and a controversy caused by recent research demonstrating that the same improvement of cardiac function could be achieved by injection of dead cardiac progenitor cells or nonspecific induction of inflammation was discussed last year. ${ }^{26}$ Although it is yet to be seen whether sustained improvement of cardiac function observed after the stem cell therapy is a result of the activation of innate immunity, many novel aspects of cardiac stem cell therapy in children have been detailed. ${ }^{26}$ As we move toward personalized precision care in children with congenital heart disease, the importance of collaboration, ${ }^{27}$ hypothesis-driven research, ${ }^{28}$ avoiding pitfalls of administrative databases, ${ }^{7,28}$ and careful preoperative surgical planning has be emphasized. $^{29}$

\section{CONCLUSIONS}

The past year revealed unique challenges brought by the pandemic, which changed many aspects of our busy lives. Rapid advancement in congenital cardiothoracic surgery combined with unprecedented isolation enforced by the pandemic demonstrated the need for easy access to focused expert options. Our Editorial Board is committed to bringing the most focused, condensed, practical, and upto-date information on the most challenging, novel, and controversial topics to our readership, which is dissected by the experts in the field.

\section{Conflict of Interest Statement}

The authors reported no conflicts of interest.

The Journal policy requires editors and reviewers to disclose conflicts of interest and to decline handling or re- viewing manuscripts for which they may have a conflict of interest. The editors and reviewers of this article have no conflicts of interest.

\section{References}

1. Buratto E, Konstantinov IE. Aortic valve surgery in children. J Thorac Cardiovasc Surg. 2021;161:244-50.

2. Hraska V, Mitchell ME, Woods RK. Roadmap for Ross procedure: staged strategy. J Thorac Cardiovasc Surg. January 31, 2021 [Epub ahead of print].

3. Weiss AJ, Pettersson GB. The Ross reversal. J Thorac Cardiovasc Surg Tech. 2021 [Epub ahead of print].

4. Buratto E, Konstantinov IE. Valve sparing aortic root surgery in children and adults with congenital heart disease. J Thorac Cardiovasc Surg. September 28, 2020 [Epub ahead of print].

5. Naimo PS, Buratto E, Konstantinov IE. Truncal valve repair in children in neonates and infants. J Thorac Cardiovasc Surg. December 8, 2020 [Epub ahead of print].

6. Savla JJ, Faerber JA, Huang YV, Zaoutis T, Goldmuntz E, Kawut SM, et al. 2Year outcomes after complete or staged procedure for tetralogy of Fallot in neonates. J Am Coll Cardiol. 2019;74:1570-9.

7. Zurakowski D, Jonas RA. The many factors leading to resurgence of the Blalock shunt for tetralogy. J Thorac Cardiovasc Surg. 2021;161:396-9.

8. Fraser CD Jr. We should reframe the discussion/debate about neonatal repair of tetralogy of Fallot. J Thorac Cardiovasc Surg. 2021;161:1421-5.

9. Mascio CE. Commentary: you like potato and I like potahto. J Thorac Cardiovasc Surg. 2021;161:400-1.

10. Burkhart HM, Thompson JL, Mir A. Commentary: is there still a role for the systemic-to-pulmonary artery shunt in tetralogy? J Thorac Cardiovasc Surg. 2021;161:401-2.

11. Herrmann JL, Brown JW. Seven decades of valved right ventricular outflow tract reconstruction: the most common heart procedure in children. J Thorac Cardiovasc Surg. 2020;160:1284-8.

12. Jaggers J. Commentary: surgical options for right ventricular outflow tract reconstruction: innovate or die. J Thorac Cardiovasc Surg. 2020;160:1289-90.

13. Tannous P, Nugent A. Transcatheter pulmonary valve replacement in native and nonconduit right ventricle outflow tracts. J Thorac Cardiovasc Surg. September 15, 2020 [Epub ahead of print].

14. Bergmann O. Cardiomyocytes in congenital heart disease: overcoming cytokinesis failure in tetralogy of Fallot. J Thorac Cardiovasc Surg. 2021;161: 1587-90.

15. John MM, McKenzie ED. Norwood procedure: how I do it. J Thorac Cardiovasc Surg Tech. 2020;4:205-7.

16. Sood V, Zampi JD, Romano JC. Hypoplastic left heart syndrome with an intact atrial septum. J Thorac Cardiovasc Surg Open. 2020;1:51-6.

17. Daley M, d'Udekem Y. The optimal Fontan operation: lateral tunnel or extracardiac conduit? J Thorac Cardiovasc Surg. December 8, 2020 [Epub ahead of print].

18. Rychik J. What "FUEL"s the Fontan circulation-solvitur ambulando! J Thorac Cardiovasc Surg. September 15, 2020 [Epub ahead of print].

19. d'Udekem Y, Thambo JB, Iyengar AJ, Rychik J. Are we getting closer to identifying the best follow-up and management after Fontan completion? J Thorac Cardiovasc Surg. July 4, 2020 [Epub ahead of print].

20. Hraska V, Hjortdal VE, Dori Y, Kreutzer C. Innominate vein turn down procedure-killing two birds with one stone. J Thorac Cardiovasc Surg Tech. 2020 [Epub ahead of print].

21. Jaggers J. Indications and timing for heart transplantation in Fontan failure. $J$ Thorac Cardiovasc Surg Open. May 13, 2020 [Epub ahead of print].

22. Rajab TK, Jaggers J. Heart transplantation in Fontan failure: the final stage. $J$ Thorac Cardiovasc Surg Open. 2020;3:154-9.

23. Dearani JA. Ebstein repair: how I do it. J Thorac Cardiovasc Surg Tech. 2020;3: 269-76.

24. Cleveland JD, Starnes VA. Simple, reproducible, and consistent physiology: the argument for single ventricle repair in critically ill neonates with Ebstein anomaly. J Thorac Cardiovasc Surg Tech. 2020 [Epub ahead of print].

25. Vida VL, Guariento A. A sword threatening the heart: the scimitar syndrome. J Thorac Cardiovasc Surg Tech. 2020;1:75-80.

26. Sano S, Sano T, Ishigami S, Ito T. Cardiac stem cell therapy: does the newborn heart have an infinite potential for stem cell therapy? J Thorac Cardiovasc Surg. September 14, 2020 [Epub ahead of print]. 
27. Laussen P. Sharing and learning through PC4: moving towards precision pediatric cardiac critical care. J Thorac Cardiovasc Surg. June 10, 2020 [Epub ahead of print].

28. Karamlou T, Javorski MJ, Weiss A, Pasquali SK, Welke KF. Utility of administrative and clinical data for clinical research: a case-based approach to guide choice. J Thorac Cardiovasc Surg. October 17, 2020 [Epub ahead of print].
29. Van Arsdell GS, Hussein N, Yoo SJ. Three-dimensional printing in congenital cardiac surgery—now and the future. J Thorac Cardiovasc Surg. 2020;160:515-9.

Key Words: aortic valve, aortic root, congenital, Ebstein anomaly, Fontan operation, scimitar syndrome, stem cells, surgery, tetralogy of Fallot, univentricular circulation 


\section{Forefront of Congenital Cardiothoracic Surgery: Recent Articles From AATS Journals}
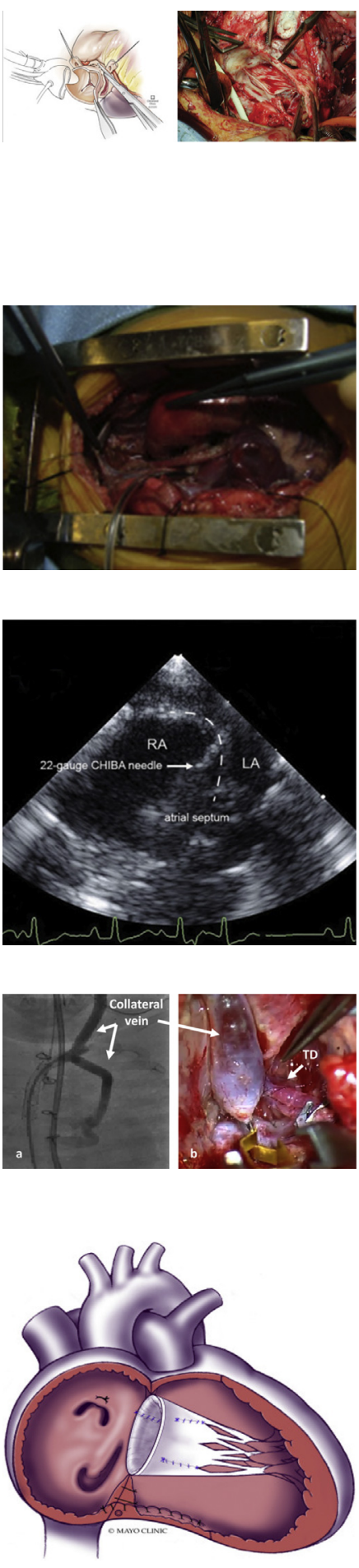

JTCVS TECHNIQUES: The Ross reversal. Weiss AJ, Pettersson GB. J Thorac Cardiovasc Surg Tech. 2021 [In Press].

Commentary: The Ross reversal: Should it be done, if so when? Mack CA, Girardi LN. J Thorac Cardiovasc Surg Tech. 2021 [In Press].

Commentary: The Ross reversal: An innovative and useful extension of the armamentarium for the failing Ross. Schmiady M0, Hübler M. J Thorac Cardiovasc Surg Tech. 2021 [In Press].

Commentary: The Ross reversal: A rare operation to be done by experts only. Bacha E. J Thorac Cardiovasc Surg Tech. 2021 [In Press].

JTCVS TECHNIQUES: Norwood procedure: How I do it. John MM, McKenzie ED. J Thorac Cardiovasc Surg Tech. 2020;4:205-207.

JTCVS OPEN: Hypoplastic left heart syndrome with an intact atrial septum. Sood V, Zampi JD, Romano JC. J Thorac Cardivasc Surg Open. 2020;1:51-56.

Commentary: It takes a village to manage a child with hypoplastic left heart syndrome and intact or highly restrictive atrial septum. Alsoufi B. J Thorac Cardiovasc Surg Open. 2020;1:57-58.

Commentary: Hypoplastic left heart syndrome with atrial septum: Planning for success. Burkhart HM, Mir A, Schwartz RM. J Thorac Cardiovasc Surg Open. 2020;1:59-60.

JTCVS TECHNIQUES: Innominate vein turn down procedure-Killing two birds with one stone. Hraska V, Hjortdal VE, Dori Y, Kreutzer C. J Thoac Cardiovasc Surg Tech. 2021 [In Press].

Commentary: Innominate turndown-A better insurance for the Fontan circulation? Sinah P. J Thorac Cardiovasc Surg Tech. 2021 [In Press].

Commentary: Fontan circulation with lymphatic failure: Was the Holy Grail finally found? Sandica E. J Thorac Cardiovasc Surg Tech. 2021 [In Press].

JTCVS TECHNIQUES: Ebstein repair: How I do it. Dearani JA. J Thorac Cardiovasc Surg Tech. 2020;3:269-276.

Commentary: Cone repair for Ebstein anomaly: It's all in the details. Overman DM. $J$ Thorac Cardiovasc Surg Tech. 2020;3:277-278.

Commentary: Devil is in the details... and good judgment! Susheel Kumar TK, Knott-Craig CJ. J Thorac Cardiovasc Surg Tech. 2020;3:279-280. 